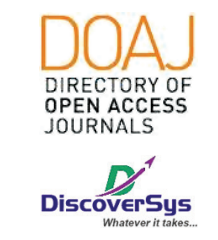

Published by DiscoverSys

\section{Profile of maxillofacial injuries in Departement of Emergency Trauma and Acute Care Surgery in Sanglah General Hospital from January 2012 to November 2018}

\author{
Anak Agung Gde Agung Anom Arie Wiradana, ${ }^{1 *}$ Ketut Wiargitha ${ }^{2}$
}

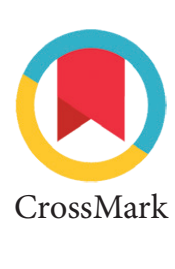

\begin{abstract}
Introduction: Maxillofacial injuries are common cause of trauma in emergency department. The goals in the treatment of maxillofacial injury are to restore premorbid occlusion. This study aimed to evaluate the characteristics and outcome of the maxillofacial injuries patient in Sanglah General Hospital Denpasar Bali.

Methods: Retrospective study was held in Sanglah General Hospital from January 2012 to November 2018. The samples consisted of 241 patients. Age, gender, type of the fractures and surgical management were evaluated.
\end{abstract}

ABSTRACT
Results: Maxillofacial injuries mostly occurred in male, aged 18-40 years old, the mandible was most frequently involved facial bone. Internal fixation was the golden standard of the treatment chosen (83.73\%) followed by Arch bar (16.27\%).

Conclusion: Road traffic accidents are the main reason for maxillofacial injury in Sanglah General Hospital Denpasar Bali. Precise diagnosis and proper treatment result in optimal occlusion and integrity nervous system, both internal fixation and arch bar were given good outcome.

Keywords: maxillofacial injury, internal fixation, arch bar occlusion.

Cite the Article: Wiradana, A.A.G.A.A.A., Wiargitha, K. 2019. Profile of maxillofacial injuries in Departement of Emergency Trauma and Acute Care Surgery in Sanglah General Hospital from January 2012 to November 2018. Intisari Sains Medis 10(2): 227-229. D0I: 10.15562/ism.v10i2.401

${ }^{1}$ General Surgery Resident, Medical Faculty, Udayana University, Sanglah General Hospital Denpasar, Bali, Indonesia ${ }^{2}$ Department of Emergency and Acute Care Surgery, Medical Faculty, Udayana University, Sanglah General Hospital Denpasar, Bali, Indonesia

*Correspondence to:

Anak Agung Gde Agung Anom Arie Wiradana, General Surgery Resident, Medical Faculty, Udayana University, Sanglah General Hospital Denpasar, Bali, Indonesia

anomwiradana@gmail.com

Received: 2019-01-22 Accepted: 2019-04-16 Published: 2019-08-01

\section{INTRODUCTION}

Emergency and Trauma Acute Care Surgery has been established since 2001 at Bali where various trauma cases are expected to be seen. Maxillofacial injury is one of the major trauma, following the increased use of motorcycles in Bali. Maxillofacial injury can be divided into the upper face (the frontal bone and frontal sinus), the midface (the nasal, ethmoid, zygomatic, and maxillary bones), the lower face (the mandible). ${ }^{1}$ The etiology varies, either caused by falls, motor vehicle accidents (MVAs), and interpersonal violence. ${ }^{2}$

In US, maxillofacial trauma was managed by plastic surgeon, maxillofacial surgeon, and otolaryngology surgeon. In Bali, maxillofacial cases were managed by either maxillofacial surgeon or plastic surgeon. ${ }^{3}$ However in emergency condition that maxillofacial trauma that poses an immediate threat to life, general surgeon should be able to manage the airway threathening. ${ }^{4}$

Treatment with osteosynthesis was the most preferred treatment option as it offers stable and precise anatomical reduction of fragments. However, this option was limited by cost in developing countries. Nowadays, ORIF miniplate was becoming popular, wither placed along with Arch bar or IMF. ${ }^{5}$ In developing countries closed reduction is preferred by the people against the open reduction. ${ }^{6}$ Even In Africa, MMF and intraosseous wiring dominated the preferred choice of treatment due to cost problem. ${ }^{7}$ In Sanglah General Hospital, the standard operating procedure of the management maxillofacial fracture was using ORIF miniplate and screws.

Maxillofacial injuries vary in different countries and cities and geographic zones, influenced by population lifestyle, cultural background, and socioeconomic status can affect the prevalence of maxillofacial injuries. ${ }^{8}$ Therefore, this study will analyze the characteristics of subjects who suffered from maxillofacial trauma for a better understanding and providing valuable information for the planning of health actions. The descriptive study of maxillofacial trauma also aim to outline the risk situations, as well as the characteristics of individuals susceptible to this type of trauma.

\section{METHODS}

This is a descriptive study, taking 241 medical records of maxillofacial injury subjects visiting Sanglah General Hospital from January 2012 to November 2018. To compose the sample, cases of people who presented facial trauma and who were treated with need for hospitalization were included. Exclusion criteria were records that were considered incomplete (lacking three or more information), 
illegible (even when, after consultation with physician or maxillofacial surgeon, the information in the medical record was not yet deciphered), resulting in 244 cases. The variables studied were age (in years), gender (female/male), type of etiological agent of the face trauma (traffic accident, interpersonal violence, falls, others such as work accident and accident during the practice of sports), type of facial trauma (based on radiology examination), and modalities of treatment. Data were tabulated and presented in table and text.

\section{RESULTS}

The injury was more common in male compared to female (male $84 \%$, female $16 \%$ ). Age 18 to 40 years old were more common (48.57\%), followed by child to adolescent (aged 0 to 18 years old) $31.43 \%$ and adult to elderly (aged 40 to 60 years old) were $20 \%$. See detail on table 1. Mandible fracture within the variation was most common occurring for $60.12 \%$,

Table 1 Demographics data of maxillofacial subjects in Sanglah General hospital

\begin{tabular}{|c|c|c|}
\hline Demographics & & Frequency (\%) \\
\hline \multirow[t]{2}{*}{ Gender } & Male & 84 \\
\hline & Female & 16 \\
\hline \multirow[t]{3}{*}{ Age } & $0-18$ years old & 26.75 \\
\hline & $18-40$ years old & 49.25 \\
\hline & 40-60 years old & 24 \\
\hline \multirow[t]{11}{*}{ Fractures } & Mandible & 60.12 \\
\hline & Alveolar mandible & 29.43 \\
\hline & Parasymphisis mandible & 48 \\
\hline & Angulus mandible & 12.86 \\
\hline & Processes alveolar mandible & 1.88 \\
\hline & Segmented & 2.34 \\
\hline & Zygomatic & 30.22 \\
\hline & Maxillary & 27.50 \\
\hline & Displaced & 15.12 \\
\hline & Alveolar maxillary & 30.24 \\
\hline & Zygomaticomaxillary & 49.99 \\
\hline \multirow[t]{5}{*}{ Mechanism of injury } & Traffic accident & 92 \\
\hline & Lack of skill & 44.45 \\
\hline & Abiding traffic law & 38.62 \\
\hline & Under influence of alcohol & 25.55 \\
\hline & Violent activity & 8 \\
\hline \multirow[t]{4}{*}{ Treatment } & ORIF miniplate & 70.12 \\
\hline & Archbarr+IDW & 6.00 \\
\hline & Archbarr+MMF & 10.27 \\
\hline & Orif miniplate + Archbarr & 13.61 \\
\hline
\end{tabular}

Other fractures such as Zygomatic fracture within the variation (30.22\%) and followed by Maxillary fracture within the variation (15.12\%). Based on mechanism of injury the commonest cause of the fracture was road traffic accident (92\%) followed by violent activities (8\%). Internal fixation was the golden standard of the treatment $(83.73 \%)$ followed by Arch bar (16.27\%) (Table 1).

\section{DISCUSSION}

Maxillofacial is the prominent site of the human body and this makes the region is prone to suffer from trauma. ${ }^{2}$ The common case of maxillofacial injury is due to traffic accident. ${ }^{2}$ In Bali, the most common mechanism of injury was road traffic accident. This was in accordance with study since 1990 that traffic accident was the most common culprit, following by assault. ${ }^{9,10}$

Maxillofacial trauma was more frequent in young adult patients, in agreement with previous findings in literature. Male is predominant in our study due to their greater participation in highrisk activity which increases their exposure to risk factors such as driving vehicles at high speeds and their social life involving alcohol and violent activity. ${ }^{11}$ The age-related of maxillofacial injuries in 18-40 years old attributed to the fact that people in this period of life are more active regarding their activities. In this study, mandible fracture was most common variation, followed by zygoma and maxillary fracture. This concurs with results from many other results from both national and international studies. The reason for preponderance of mandible was due to its prominence, mobility and its selection as a target of intentional violence. ${ }^{12-14}$

Low level of awareness among population to wear full face helmet (Indonesian National Standard with chin protection) does impact the number of maxillofacial injury at Indonesia especially in Bali. Diagnosing maxillofacial trauma in our hospital was standardized. Physical examination leads to the decision to do further radiology examination. X-ray examination of skull anteroposterior/lateral aspect and panoramic are the cheapest and the most common photos that can be done. More sophisticated examination such as CT Scan could give the more detail view regarding of the type of fracture with more exposure..$^{15}$ For the reduction, there are many options, which may differ depending on many factors like cost of treatment, feasibility of hospital, doctor's decision, patient's willingness to obey the treatment advised. ${ }^{16}$ In our hospital, before the new agreement between hospital and insurance provider agreed to cover the cost of ORIF miniplate, majority of the patients were treated with closed reduction with arch bar fixation. 
Since the insurance cover the cost of miniplate in 2001, open reduction and internal fixation become the first choice. The surgical approach carried out was intraoral sublabial, coronal, transcutaneous, transconjunctival, and subsidiary approach.

Maintenance of proper oral hygiene, both preand postoperatively, is an important treatment adjunct in the management of mandible fractures. Loss of tissue barriers to bacterial invasion due to compound fractures in the line of teeth, gingival tears, hematomas, edema, and interference with natural cleaning mechanisms all increase infection risk. Proper oral hygiene using saline, peroxide, or medicated (chlorhexidine gluconate) rinses should be encouraged. Postoperative steroids and the use of ice compresses can be effective at reduction of edema. ${ }^{15,16}$

\section{CONCLUSION}

Maxillofacial injuries were usually suffered by males in productive ages, in which the most susceptible segment of injury was mandible. Management varies, with the gold standard of ORIF miniplate, together with Arch bar and interdental wiring fixation.

\section{CONFLICT OF INTEREST}

The author declare there is no conflict of interest.

\section{FUNDING}

Current study doesn't receive any specific grant from government or any private sector.

\section{REFERENCES}

1. Brunicardi FC. Schwartz's Principal of Surgery ninth edition Maxillofacial Injury: Lippincott William and Wilkins: Philadelphia. 2003: p. 169

2. Ribeiro M, Marcenes W, Croucher R, Sheiham A. The prevalence and causes of maxillofacial fractures in patients attending Accident and Emergency Departments in Recife-Brazil. Int Dent J. 2014;54:47-51.
3. Tuckett JW, Lynham A, Perry UH. Maxillofacial trauma in the emergency department: A review. The Surgeon. 2014;12(2):106-114.

4. Jose A, Nagori SA, Agarwal B, Bhutia O, Roychoudhury A. Management of maxillofacial injury. Journal of Emergencies Trauma and Shock. 2016:1(1):1-5.

5. Bali R, Sharma P, Jindal S, Sharma R. Bone resorption after bioresorbable fixation of a fractured pediatric mandible - a case report. Oral Surg. 2010;4:48-50

6. Al Ahmed HE, Jaber MA, Abu Fanas SH, Karas M. The pattern of maxillofacial fractures in Sharjah, United Arab Emirates: a review of 230 cases. Oral Surg Oral Med Oral Pathol Oral Radiol Endod. 2004;98;166-70

7. Omic J, Stephensen K. Oral maxillofacial fractures seen at a ugandan tertiary hospital: a six-month prospective study. Clinics 2009;64(9):302-308.

8. Ribeiro M, Marcenes W, Croucher R, Sheiham A. The prevalence and causes of maxillofacial fractures in patients attending Accident and Emergency Departments in Recife-Brazil. Int Dent J. 2004;54:47-51.

9. Haug RH, Prather J, Indresano AT: An epidemiologic survey of facial fractures and concomitant injuries. J Oral Maxillofac Surg. 1990;48:926-8.

10. McCabe JB, Angelos MG: Injury to the head and face in patients with cervical spine injury. Am J Emerg Med. 1984;333(2):1984 5.

11. Singh JK, Lateef M, Khan MA, Khan T. Clinical study of maxillofacial trauma in Kashmir. Indian J Otolaryngol Head Neck Surg. 2005;57(1):24-7.

12. Desai J, Lownie JF, Cleanton JPE. Prospective audit of mandibular fractures at the Charlotte Maxeke Johannesburg Academic Hospital. SAJS. 2010;48(4):12-126.

13. Adeyemo WL, Ladeinde AL, Ogunlewe $\mathrm{MO}$ and James $\mathrm{O}$. Trends and characteristics of oral and maxillofacial injuries in Nigeria: a review of the literature. Head and Face Medicine. 2005;1(7):15-19.

14. Shayyab M, Alsoleihat F, Ryalat S and Khraisat A. Trends in the Pattern of Facial Fractures in Different Countries of the World. Int. J Morphol. 2012;30(2):745-756.

15. Alex M, Greenberg DDS, Joachim Prein. Craniomaxillofacial Reconstructive and Corrective Bone Surgery: Principles of Internal Fixation Using the $\mathrm{AO} /$ ASIF Technique. Int J Maxilo Sci. 2002;14(2):147-152.

16. Jamal BT, Diecidue R, Qutuo A, et al: The pattern of combined maxillofacial and cervical spine fractures. J Oral Maxillofac Surg. 2009;67:559-63.

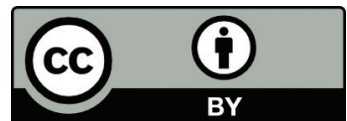

This work is licensed under a Creative Commons Attribution 